\title{
EFFECT OF WEIGHT AND STRAIN ON THE EGG COMPONENT UTILIZATION AND EMBRYONIC WEIGHT DURING INCUBATION
}

\author{
EFECTO DEL PESO Y LA LÍNEA, SOBRE LA UTILIZACIÓN DE LOS \\ COMPONENTES DEL HUEVO Y PESO EMBRIONARIO DURANTE LA INCUBACIÓN
}

\author{
Egbeyale, L.T. ${ }^{1 *}$; Sogunle, O.M. ${ }^{1}$; Abiola, S.S. ${ }^{1}$;Ozoje, M.O. ${ }^{2}$; Sowande, O.S. ${ }^{1}$ and Adeleye, O.O. ${ }^{1}$ \\ 'Department of Animal Production and Health. Federal University of Agriculture. Abeokuta. Nigeria. \\ ${ }^{2}$ Department of Animal Breeding and Genetics. Federal University of Agriculture. Abeokuta. Nigeria. \\ *egbeyalelt@unaab.edu.ng
}

\section{ADDITIONAL KEYWORDS \\ Dominant Black pullets. Yaffa Brown pullets.}

\section{SUMMARY}

The study was conducted to determine the effect of egg size on egg components utilization and embryonic weight during incubation of Dominant Black (DB) and Yaffa Brown (YB) strains of pullet eggs. A total of 810 hatching pullet eggs (405 eggs per strain) were grouped into three egg sizes (small, medium and large) per strain resulting in six treatment groups which were replicated three times with 45 eggs per replicate. Two eggs per replicate were used to determine the embryonic, albumen and yolk weight on each of the days $1,7,10,15$, and 18 of incubation resulting into a total of 180 eggs. Data obtained were subjected to analysis of variance in a $2 \times 3$ factorial experimental layout. Results revealed a significant $(p<0.05)$ increase in albumen percentage as egg weight increased $(r=0.93)$ in both strains before incubation. The albumen weight decreased steadily to zero from day 1 till the end of incubation while the rate of yolk weight did not show the same pattern. The ranged values of albumen percentage for large, medium and small eggs were; $58.89 \pm$ 10.78 to $1.75 \pm 0.56,56.83 \pm 0.55$ to $0.61 \pm 0.28$ and $54.04 \pm 1.81$ to $5.42 \pm 0.89$, respectively. At $18^{\text {th }}$ day, the embryonic weights of both medium and large-sized eggs ( 28.56 and $28.80 \mathrm{~g}$, respectively) were significantly $(p<0.05)$ higher than small-sized eggs (22.54). It could be concluded that the rate of albumen utilization during incubation influenced the embryonic weight $(r=-0.97)$. Also the high content of yolk when compared with that of albumen towards the end of incubation in the three

\section{Palabras clave adicionales}

Pollitas Dominant Black. Pollitas Yaffa Brown.

groups could result from the need for energy and protein by the developing embryo after hatching before access to any feed.

\section{RESUMEN}

Se determinó el efecto del tamaño sobre la utilización de los componentes del huevo y peso embrionario durante la incubación de huevos de las líneas Dominant Black (DB) y Yaffa Brown (YB). Un total de 810 huevos (405 por línea), fueron agrupados en tres tamaños por línea (pequeños, medios y grandes) dispuestos en seis grupos experimentales con tres replicaciones de 45 huevos cada una. Un total de 180 huevos, dos por repetición, fueron usados para determinar el peso de albumen y yema embrionarios los días 1 , 7, 10, 15 y 18 de la incubación. Los resultados fueron sometidos a análisis de varianza en una disposición factorial $2 \times 3$. En ambas líneas, antes de la incubación, se registró un aumento $(p<0,05)$ del porcentaje de albumen al hacerlo el peso del huevo $(r=0,93)$. El peso del albumen disminuyó hasta cero de forma sostenida desde el día 1 hasta el final de la incubación, aunque la proporción de yema no siguió el mismo modelo. Los rangos de porcentaje de albumen fueron los siguientes de $58,89 \pm 10,78$ a $1,75 \pm 0,56$, para los huevos grandes, de $56,83 \pm 0,55$ a $0,61 \pm 0,28$, para los medianos y de $54,04 \pm 1,81$ a $5,42 \pm 0,89$ para los pequeños. El día 18 los pesos embrionarios de los huevos medianos y grandes $(28,56$ y $28,80 \mathrm{~g}$, 
respectivamente) fueron $(p<0,05)$ mayores que los de los huevos pequeños $(25,24)$. La tasa de utilización del albumen durante la incubación influyó sobre el peso embrionario $(r=-0,97)$. Asimismo el alto contenido de yema respecto al albumen hacia el final de la incubación, en los tres grupos, sería la consecuencia de las necesidades de energía y proteína del embrión en desarrollo, después de la incubación, antes de acceder a algún alimento.

\section{INTRODUCTION}

Hatching eggs from chicken require interactions between several factors to promote the development of the embryo to hatch at the appropriate duration of incubation. These factors include the genetic line and age of the breeder, the egg weight, and factors related to the environment in which the egg is stored and incubated, such as temperature, humidity, gas levels and altitude. Egg handling such as turning also has some effects on hatchability. Embryonic development is a dynamic process that requires a fine balance between these environmental factors in order to achieve an optimum hatchability and chick quality. Because there are differences in the quality of hatching eggs from different lines of breeders, breeders of different ages, eggs stored under different conditions and even eggs of different weights, it is becoming apparent that different eggs may require different incubation conditions (Onagbesan etal., 2007).

Transfer of nutrients from the hen to the egg follows two pathways: via the ovary to the yolk or via the oviduct to the albumen, egg shells, and membranes. Chemically, the transference of nutrients from the hen to the ovary and the oviduct involves the synthesis and the export of proteins able to bind specific molecules. Inside the egg, the embryo develops specific mechanisms to mobilize previously stored vitamins and minerals by means of transport proteins. Nutrient absorption, metabolism, and deposition vary with hens' genetics (Lillie et al., 1951). Marginal deficiencies can significantly affect some chickens in a flock but not others, leading to high embryonic mortality at the end of incubation (Wilson, 1997). High mortality during the second week of incubation of chicken embryos suggests nutrient deficiencies in hens' diets, as normal mortality rates are very low during this period (Leeson et al., 1979). Excesses, as well as deficiencies, can affect embryo development, and may interrupt egg production by the hen. As nutrient deficiency or excess advanced and become severe, effects on embryo development aggravate, and become evident early (Wilson, 1997). There is scanty information on the rate of utilization of egg components of different egg weights by the developing embryo during incubation of pullet eggs. Therefore, this study is designed to determine the trend of egg components utilization by the developing embryos from different weights of pullet eggs.

\section{MATERIALS AND METHODS}

\section{LOCATIONOF THE EXPERIMENT}

This experiment was conducted at University of Agriculture, Abeokuta (UNAAB)-Leventis Agro Industrial limited hatchery, Kotopo, Abeokuta, Ogun State, Nigeria. The Institution falls within the rain forest vegetation zone of South-Western Nigeria on latitude $7^{\circ} 13^{\prime} 49.46^{\prime \prime} \mathrm{N}$, longitude $3^{\circ} 26^{\prime} 11.98^{\prime \prime} \mathrm{E}$ and altitude of 76 meters above sea level. The climate is humid with a mean annual rainfall of $1037 \mathrm{~mm}$. The annual mean temperature and humidity are $34.7^{\circ} \mathrm{C}$ and $82 \%$ respectively.

\section{SOURCE OF MATERIALS AND DESIGN}

A total of eight hundred and ten (810) hatching eggs of different sizes from Dominant Black and Yaffa Brown strains of pullet (i.e. 405 eggs per strain) were bought from a reliable breeder farm in Ogun State. The eggs from each strain were weighed and arranged into three (3) groups i.e small 
(41.09-50.97g), medium(50.98-57.39g) and large (57.40 - $69.64 \mathrm{~g})$. Each treatment group contained one hundred and thirty five (135) eggs which were sub-divided into three (3) replicates of forty (45) eggs each in a $2 \times 3$ factorial design.

\section{EGg MANAGEMENT}

Potassium tetraoxomanganate VII $\left(\mathrm{KMnO}_{4}\right)$ and formalin $(\mathrm{HCHO})$ at ratio 1:2 were used as fumigant for the eggs. The treatment lasted for 20 minutes in a closed chamber. The eggs were set in egg trays with broad ends upward to prevent rupture of air cell. Each egg was numbered prior to setting and a separate compartment was available for each egg to facilitate data collection on individual basis. Egg turning was automatic which was on hourly basis. This was to prevent developing embryos from adhering to the shell and to ensure uniform distribution of nutrients.

\section{INCUBATION WEIGHTLOSS}

The eggs were weighed before setting and on the $18^{\text {th }}$ day, incubation weight loss was determined using the formula below:

Weight loss $(\mathrm{g})=$ Initial weight - final weight Weight loss $(\%)=$ weight loss $(g) \times 100 /$ Initial weight $(\mathrm{g})$

\section{EMBRYONICDEVELOPMENT}

At days 1, 7, 10, 15 and 18 of incubation, six (6) eggs from each treatment were gently broken to determine weight of growing embryos and the amount of remaining yolk and albumen and moisture loss. After breaking, each embryo was carefully removed and separated from all attachments such as yolk sac and chorioallantoic membrane. The remaining thick albumen and yolk were separated from the embryonic fluid before they were weighed separately.

All data collected were subjected to twoway analysis of variance (ANOVA) in a $2 x$ 3 factorial experimental layout (SAS, 1999) while significantly $(\mathrm{p}<0.05)$ different means were compared using Duncan's Multiple Range Test in the software package.

\section{Model}

$Y_{i j k}=\mu+S_{i}+E_{j}+(S E)_{i j}+\Sigma_{i j k}$

where:

$\mathrm{Y}_{\mathrm{ijk}}=$ Dependent variable,

$\mu=$ Population mean,

$S_{i}=$ Effect of $i^{\text {th }}$ strain $(i=1-2)$,

$E_{i}=$ Effect of $j^{\text {th }}$ egg size $(j=1-3)$

$(\mathrm{SE})_{\mathrm{ij}}=$ Effect due to interaction between strain and egg size,

$\Sigma_{\mathrm{ijk}}=$ Residual error with zero mean and variance $\left(\delta^{2}\right)$.

\section{RESULTS}

Rate of gradual decrease in albumen mass during incubation of different egg sizes is presented in figure 1. There was little or no change in albumen content within the first seven days of incubation but there was significant decrease in its content from seventh $\left(7^{\text {th }}\right)$ day till the last day of incubation. At the end of incubation $\left(18^{\text {th }}\right.$ day), the albumen content in both the medium

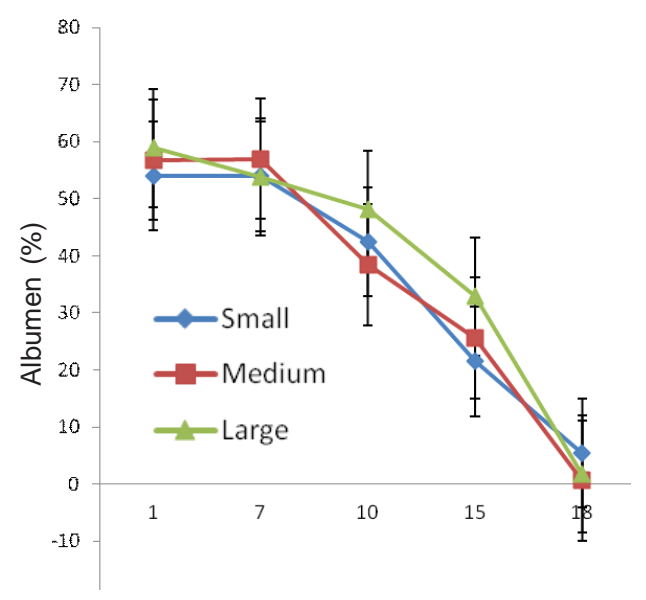

Days of incubation

Figure 1. Rate of gradual decrease in albumen mass during incubation of different egg sizes. (Tasa de disminución del albumen durante la incubación de huevos de diferentes tamaños). 
and large-sized eggs had reduced to almost zero while small-sized eggs had little amount left. Figure 2 showed the rate of albumen consumption during incubation period of DB and YB. The trend of albumen consumption was similar to that of figure 1 .

Yolk utilization during incubation of different egg sizes (figure 3) showed a decrease in its content during the first seven days of incubation but later increased (relative to egg weight) till the $10^{\text {th }}$ day. The yolk mass showed a sharp downward trend till day 15 and gradual decrease till day 18 of incubation. The values at the $18^{\text {th }}$ day for each size were in accordance to the initial yolk value. In the same vein, the graphical presentation of effect of strain on yolk utilization during incubation presented in figure 4 showed the same trend with that of different egg sizes. The results showed that DB had a greater value $(29.03 \%)$ of yolk mass at the initial stage but at day 10 of

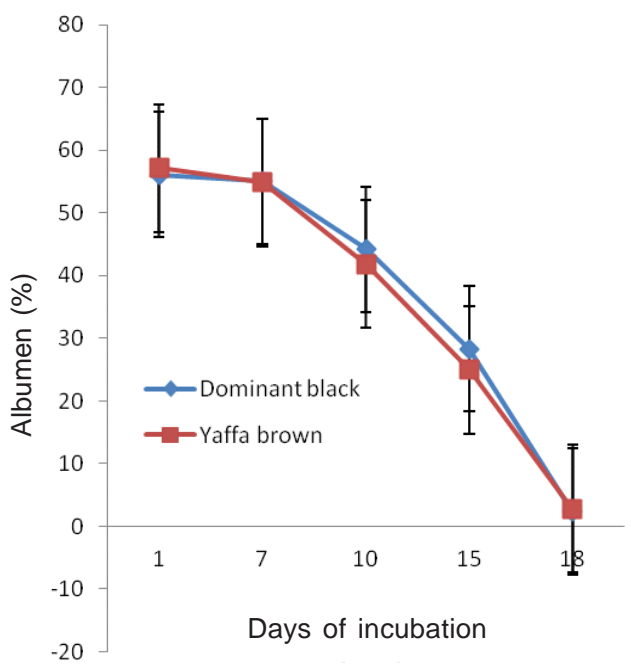

Figure 2. Rate of gradual decrease in albumen composition during incubation of Dominant Black and Yaffa Brown chicken eggs. (Reducción gradual del albumen durante la incubación de huevos de las líneas Dominant Black y Yaffa Brown).

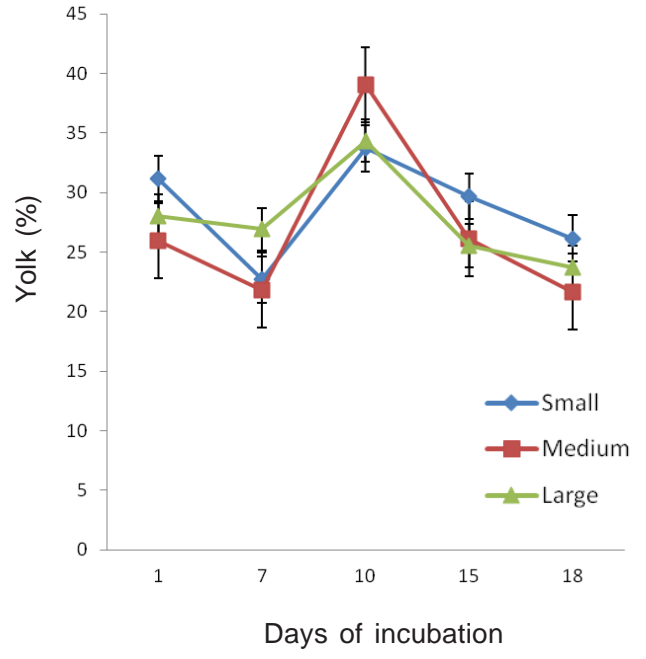

Figure 3. Rate of changes in yolk mass during incubation of different egg sizes. (Cambios en la cantidad de yema durante la incubación de huevos de diferente tamaño).

incubation, the value for YB outshot that of DB. The value of yolk mass for YB reduced sharply between day 10 and 15 while gradual decrease was observed between day 15 and 18 but the decrease in the values of DB was gradual from day 10 till 18 of incubation.

Figure 5 showed the rate of moisture loss during incubation of different egg sizes. The rate increased throughout the period of incubation for small-sized and large-sized eggs while medium-sized eggs decreased between days 10 and 15 but later increased between days 15 and 18 . The difference in moisture loss during incubation of DB and YB hatching egg is presented in figure 6. Yaffa Brown had an increase in moisture loss from days 1 to 10 of incubation. This level was maintained till day 15 and gradually decreased till $18^{\text {th }}$ day while the rate of moisture loss in Dominant Black increased from day 1 till 15 and the value was maintained up to day 18 .

The relative embryonic weights for 


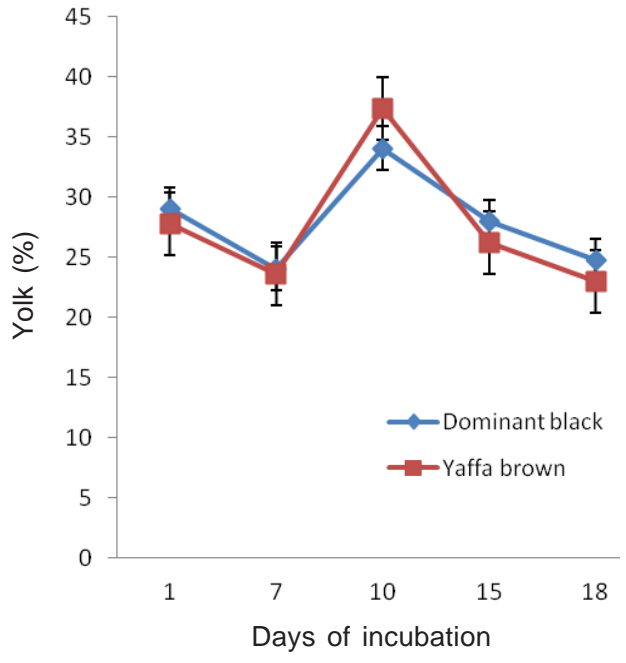

Figure 4. Rate of changes in yolk mass during incubation of Dominant Black and Yaffa Brown chicken eggs. (Cambios en la cantidad de yema durante la incubación de huevos de las líneas Dominant Black y Yaffa Brown).

different egg sizes during the incubation period are shown in figure 7 . The rate of embryonic development at the early stage

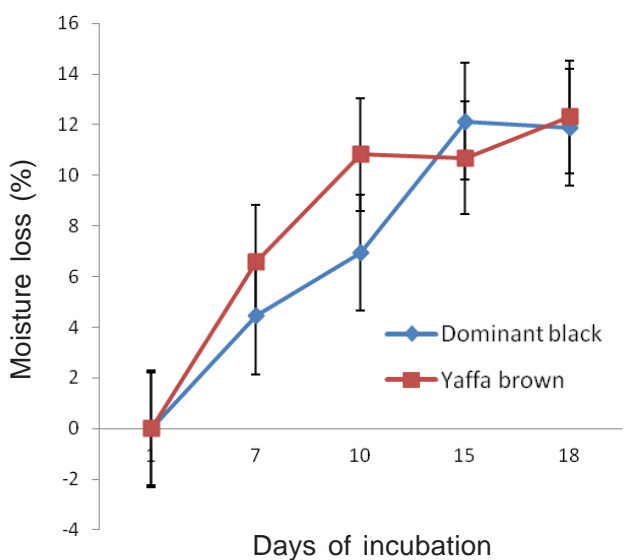

Figure 6. Incubation moisture losses in Dominant Black and Yaffa Brown chicken eggs. (Pérdidas de humedad durante la incubación de huevos de las líneas Dominant Black y Yaffa Brown).

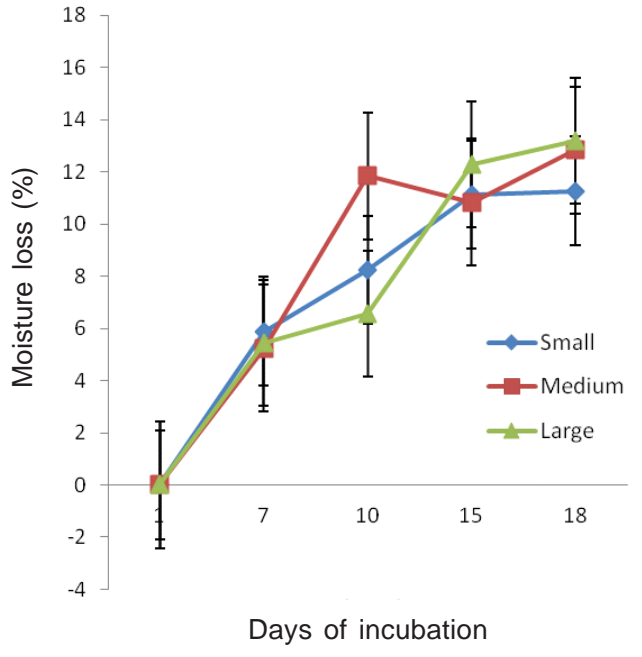

Figure 5. Rate of moisture loss during incubation of different egg sizes. (Pérdidas de humedad durante la incubación en huevos de diferentes tamaños).

of incubation was gradual till day 10 but a rapid increase was observed from day 10 till the end of incubation period. It was

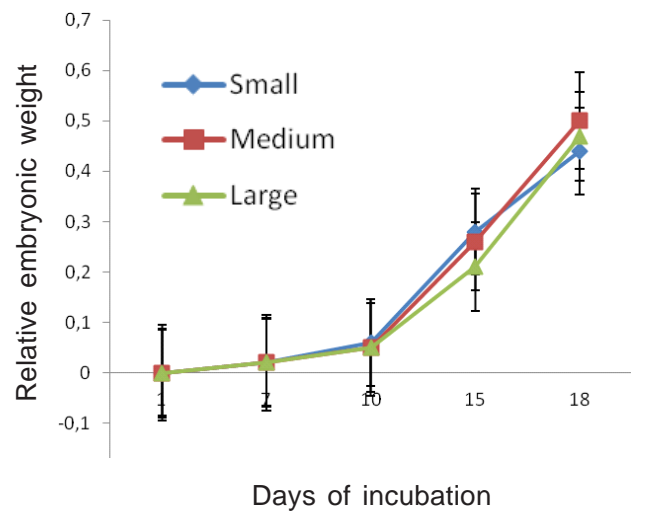

Figure 7. Relative embryonic development and weight of different egg sizes during incubation. (Desarrollo relativo del embrión durante la incubación de huevos de diferente tamaño). 
observed that the rate of embryonic development in large-sized egg was slower compared to other categories till day 17 but outshot small-sized eggs towards the end of incubation. On the $18^{\text {th }}$ day, mediumsized eggs had highest value $(0.50)$ followed by large-sized eggs (0.47) while the smallsized eggs had the least value of 0.44 . The rate of embryonic development relative to egg size is presented in figure 8 . The rate of development in each strain was slower at the early days (days 1 to 10) of incubation but later exhibited faster growth rate between days 10 and 18 . It was shown that DB had higher values from day 7 to day 16 but the two strains had the same weight till day 18.

The effect of interaction between egg size and strain on the albumen and yolk utilization during incubation is presented in the table $\mathbf{I}$. The values of albumen and yolk percentage were not significantly $(p>0.05)$ different before incubation while the consequent values during the days of

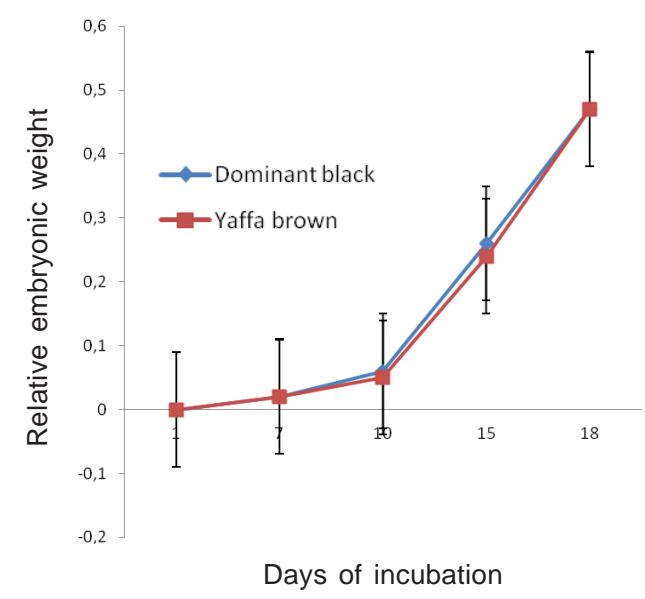

Figure 8. Relative embryonic development and weight of Dominant Black and Yaffa Brown chickens during incubation. (Desarrollo relativo del embrión durante la incubación de huevos de las líneas Dominant Black y Yaffa Brown). incubation were influenced $(\mathrm{p}<0.05)$ by the effect of interaction between egg sizes and strain of the birds. It was only yolk values that were not significant $(\mathrm{p}>0.05)$ on the $18^{\text {th }}$ day of incubation.

\section{DISCUSSION}

The eggs produced by breeder hens just coming into lay are relatively smaller when compared with those that have being in lay for sometimes. An evaluation of indices related to hatchability is required when these eggs are to be used for the production of chicks (Pedroso et al., 2005). The data obtained on increase in the proportion of albumen with increase in egg size in this study corroborate the findings of Finkler $e t$ al. (1998) who reported that with increasing egg size there is an increase in the amount of albumen and a decrease in the proportion of yolk. Such correlation may confound tests of the relative influence of each egg component on the mass and composition of the embryo. Hence, egg size influences the weight of its components.

The high content of yolk when compared with that of albumen during incubation period as observed in the three groups could be as a result of the need for energy and protein by the developing embryo after hatching before having access to any feed. In the developing poultry embryo the sole energy supply is yolk. Towards the end of the incubation period yolk is internalized into the abdominal cavity. At hatch, yolk comprises approximately $20 \%$ of the body weight (BW) of chicks and provides immediate post hatch energy and protein for maintenance and growth (Noy and Sklan, 2002). The high content of yolk in small eggs observed at the end of incubation is in agreement with the report of Tullett and Noble (1989) who noted that the transfer of lipid from the yolk to the embryo is much reduced in eggs from young parent stock. In the same vein, the low moisture loss in small-sized egg may be due to the age of 


\section{EGG CHARACTERISTICS AND EMBRYONIC WEIGHT DURING INCUBATION}

Table I. Effect of interaction between egg size and strains of bird on egg components utilization during incubation. (Efecto de la interacción del tamaño del huevo y línea sobre la utilización de los componentes del huevo durante la incubación).

\begin{tabular}{|c|c|c|c|c|c|c|}
\hline & Domin & hant Black (egg & g size) & Yaffa & Brown (egg & size) \\
\hline & small & medium & large & small & medium & large \\
\hline efore incubation & & & & & & \\
\hline Initial egg weight (g) & $50.67 \pm 1.45^{d}$ & $57.67 \pm 0.88^{b c}$ & $64.00 \pm 1.73^{a}$ & $50.33 \pm 1.76^{d}$ & $55.00 \pm 0.58^{\circ} \epsilon$ & $60.67 \pm 1.45^{\mathrm{ab}}$ \\
\hline Albumen (\%) & $53.79 \pm 2.94$ & $56.09 \pm 0.93$ & $58.37 \pm 0.83$ & $54.28 \pm 2.78$ & $57.58 \pm 0.31$ & $59.41 \pm 1.44$ \\
\hline Yolk weight (\%) & $32.50 \pm 4.67$ & $26.46 \pm 4.38$ & $28.14 \pm 0.86$ & $29.85 \pm 2.00$ & $25.45 \pm 0.95$ & $27.98 \pm 1.09$ \\
\hline Day 7 & & & & & & \\
\hline Albumen (\%) & $55.03 \pm 1.73^{\mathrm{ab}}$ & $58.77 \pm 3.49^{\mathrm{a}}$ & $51.25 \pm 1.41^{\mathrm{b}}$ & $52.80 \pm 2.34^{\mathrm{ab}}$ & $55.27 \pm 2.25^{\mathrm{ab}}$ & $56.39 \pm 0.25^{\mathrm{ab}}$ \\
\hline Yolk n & $21.47 \pm 0.53^{b}$ & $21.87 \pm 2.33^{b}$ & $28.81 \pm 1.21^{\mathrm{a}}$ & $23.90 \pm 1.48^{\mathrm{b}}$ & $21.76 \pm 1.40^{\mathrm{b}}$ & $25.01 \pm 0.67^{\mathrm{a}}$ \\
\hline REW (\% & $2.19 \pm 0.27^{a}$ & $1.83 \pm 0.08^{a}$ & $1.45 \pm 0.12^{\mathrm{b}}$ & $1.33 \pm 0.19^{b}$ & $1.81 \pm 0.21^{\mathrm{a}}$ & $2.00 \pm 0.14^{a}$ \\
\hline Day & & & & & & \\
\hline Albumen (\%) & $39.79 \pm 1.37^{b c}$ & $41.79 \pm 1.97^{a b c}$ & $50.88 \pm 4.68^{a}$ & $45.20 \pm 2.94^{\mathrm{ab}}$ & $35.12 \pm 1.19^{c}$ & $45.22 \pm 3.92^{\mathrm{ab}}$ \\
\hline Yolk weight (\%) & $33.21 \pm 0$ & 32.12 & $38.82 \pm 0.72^{b}$ & $34.23 \pm 3.04^{b}$ & $45.95 \pm$ & $31.91 \pm 1.03^{b}$ \\
\hline REW (\%) & $6.58 \pm 0.45^{\mathrm{a}}$ & $5.37 \pm 0.29^{b}$ & $4.82 \pm 0.23^{b}$ & $5.03 \pm 0.46^{b}$ & $5.01 \pm 0.15^{b}$ & $5.31 \pm 0.60^{b}$ \\
\hline & & & & & & \\
\hline Albumen (\%) & $21.49 \pm 0.15^{d}$ & $27.28 \pm 0.45^{b c}$ & $36.23 \pm 0.94^{a}$ & $21.48 \pm 0.35^{d}$ & $23.90 \pm 1.27^{\mathrm{cd}}$ & $29.48 \pm 2.57^{b}$ \\
\hline eight (\%) & $28.66 \pm 0.21^{a b}$ & $28.34 \pm 0.25^{\mathrm{abc}}$ & $26.98 \pm 0.70^{\mathrm{abc}}$ & $30.72 \pm 0.13^{\mathrm{a}}$ & $23.91=$ & $24.06 \pm 1.79^{\mathrm{bc}}$ \\
\hline REW (\%) & $29.26 \pm 0.09^{a}$ & $25.59 \pm 0.47^{c}$ & $22.49 \pm 0.56^{d}$ & $27.27 \pm 0.51^{b}$ & $25.64 \pm 0.40^{c}$ & $19.97 \pm 0.16^{e}$ \\
\hline & & & & & & \\
\hline Albun & $4.56 \pm 1.13^{\mathrm{ab}}$ & $0.63 \pm 0.63^{c}$ & $1.88 \pm 1.08^{\mathrm{bc}}$ & $6.29 \pm 1.38^{\mathrm{a}}$ & $0.59 \pm 0.07^{c}$ & $1.62 \pm 0.62^{\mathrm{bc}}$ \\
\hline Yolk we & $29.06 \pm 5.77$ & $21.85 \pm 0.91$ & $23.20 \pm 1.63$ & $23.25 \pm 1.57$ & $21.48 \pm 0.53$ & $24.21 \pm 1.88$ \\
\hline REW (\%) & $41.46 \pm 6.28^{b}$ & $52.75 \pm 0.88^{a}$ & $46.28 \pm 3.59^{\mathrm{ab}}$ & $45.87 \pm 0.22^{\mathrm{ab}}$ & $47.43 \pm 1.47^{\mathrm{ab}}$ & $47.91 \pm 0.58^{\mathrm{ab}}$ \\
\hline
\end{tabular}

$\mathrm{REW}=$ Relative embryonic weight (\%).

abcdmeans in the same row with different superscripts differ significantly $(p<0.05)$.

breeder flock because eggs from early production breeder flocks tend to have thicker eggshells and albumen, which together have appreciably lower moisture loss, vital gas exchange (Brake et al., 1997), and nutrient availability to the embryo (Benton and Brake, 1996). These influences may result in compromised viability of the embryo during the very early stages of development (Benton and Brake, 1996) and decreases in hatchability (Peebles and Brake, 1987). The low value of albumen obtained in all the groups at the end of incubation in this study could be related to the effective turning of the eggs during incubation resulting into its proper utilization by the developing embryos. Tona et al. (2005) reported that turning treatments showed advantages in enhancing albumen use and growth reflecting advanced development of embryos from turned eggs compared with unturned ones.

The continual loss of water during incubation period through the eggshell, along with the compartmentalization of water throughout the egg, serve in embryonic osmoregulation despite the maintenance of a consistent total egg water content with 


\section{EGBEYALE, SOGUNLE, ABIOLA, OZOJE, SOWANDE AND ADELEYE}

the oxidation of yolk and the production of metabolic water (Ar, 1990; Davis et al., 1988). Eggshell permeability, as measured by egg moisture loss at the end of incubation was significantly affected by egg sizes. The variation did not follow a particular trend and could not be explained because the least value $(14.25 \%)$ was from mediumsized eggs while small-sized eggs recorded highest moisture loss of $17.22 \%$. Although, the values obtained were similar to the findings of Egbeyale et al. (2010) on broiler eggs, the rates of incubation weight loss between the two strains were similar; this could have resulted from similarity in

\section{REFERENCES}

Ar, A. 1990. Egg water movement during incubation. In: Tullet, S.G. (Ed.). Avian incubation. Butterworth-Heinmann. London. pp. 157-173.

Benton Jr., C.E. and Brake, J. 1996. The effect of broiler breeder age and length of egg storage on egg albumen during early incubation. Poultry Sci, 75: 1069-1075.

Brake, J.; Walsh, T.J.; Benton Jr., C.E.; Petitte, J.N.; Meiherhof, R. and Peñalva, G. 1997. Egg handling and storage. Poultry Sci, 76: 144-151.

Davis, T.A.; Shen, S.S. and Ackerman, R.A. 1988. Embryonic osmoregulation: consequences of high and low water loss during incubation of the chicken egg. J Exp Zool, 245: 144-156.

Egbeyale, L.T.; Abiola, S.S.; Fanimo, A.O.; Oduguwa, O.O. and Sogunle, O.M. 2010. Effect of chemical treatments on microflora species on eggshell and hatchability of broiler eggs. Nig $J$ Anim Prod, 37: 25-33.

Finkler, M.S.; Van Ormaná, J.B. and Sotherland, P.R. 1998. Experimental manipulation of egg quality in chickens: influence of albumen and yolk on the size and body composition of near-term embryos in a precocial bird. J Comp Physiol B, 168: 17-24.

Leeson, S.; Reinhart, B.S. and Summers, J.D. 1979. Response of White Leghorn and Rhode Island Red breeder hens to dietary deficiencies of synthetic vitamins. 2. Embryo mortality and abnormalities. Can J Anim Sci, 59: 569-575.

Lillie, R.J.; Olsen, M.W. and Bird, H.R. 1951. Variation in reproductive response of hens to dietary eggshell permeability of the two strains.

\section{CONCLUSION}

It could be concluded that the rate of albumen utilization during incubation influenced the embryonic weight $(\mathrm{r}=-0.97)$. Also the high content of yolk when compared with that of albumen towards the end of incubation in the three groups could result from the need for energy and protein by the developing embryo after hatching before access to any feed. However, the embryonic weights of the two strains at $18^{\text {th }}$ day of incubation were similar.

deficiency. Poultry Sci, 30: 92-97.

Noy, Y. and Sklan, D. 2002. Nutrient use in chicks during the first week post-hatch. Poultry Sci, 81: 391-399.

Onagbesan, O.; Bruggeman, V.; De Smit, L.; Debonne, M.; Witters, A.; Tona, K.; Everaert, N. and Decuypere, E. 2007. Gas exchange during storage and incubation of avian eggs: effect on embryo genesis, hatchability, chick quality and post-hatch growth. World Poultry Sci J, 63: 557-573.

Pedroso, A.A.; Andrade, M.A.; Café, M.B.; Leandro, N.S.M.; Menten, J.F.M. and Stringhini, J.H. 2005. Fertility and hatchability of eggs laid in the pulletto-breeder transition period and in the initial production period. Anim Prod Sci, 90: 355-364.

Peebles, E.D. and Brake, J. 1987. Eggshell quality and hatchability in broiler breeder eggs. Poultry Sci, 66: 596-604.

SAS Institute. 1999. SAS User's Guide: Statistics. SAS Institute Inc. Cary, N.C. pp. 923.

Tona, K.; Onagbesan, O.; Bruggeman, V.; Mertens, K. and Decuypere, E. 2005. Effects of turning duration during incubation on embryo growth utilization of albumen and stress regulation. Poultry Sci, 84: 315-320.

Tullett, S.G. and Noble, R.C. 1989. Low hatchability problems in young parent stock. Poult Misset, 4: 8-9.

Wilson, H.R. 1997. Effects of maternal nutrition on hatchability. Poultry Sci, 76: 134-143. 